\title{
Chemical characteristics, aerobic stability, and microbiological counts in corn silage re-ensiled with bacterial inoculant
}

\author{
Mateus Merlo Coelho(1), Lúcio Carlos Gonçalves ${ }^{(1)}$, José Avelino Santos Rodrigues(2), \\ Kelly Moura Keller ${ }^{(1)}$, Gustavo Vinícius de Souza dos Anjos ${ }^{(1)}$, Daniel Ottoni(1), \\ Pedro Henrique Fulgêncio Michel ${ }^{(1)}$ and Diogo Gonzaga Jayme ${ }^{(1)}$
}

\begin{abstract}
(1)Universidade Federal de Minas Gerais, Escola de Medicina Veterinária, Departamento de Ciência Animal, Caixa Postal 567, CEP 31270-901 Belo Horizonte, MG, Brazil. E-mail: merlocoelho@gmail.com, luciocg@vet.ufmg.br, kelly.medvet@gmail.com, gustavosouzavet@yahoo.com.br, daniel.ottoni@hotmail.com,phfmichel@gmail.com, diogogj@gmail.com ${ }^{(2)}$ Embrapa Milho e Sorgo, Caixa Postal 151, CEP 35701-970 Sete Lagoas, MG, Brazil. E-mail: avelino.rodrigues@embrapa.br
\end{abstract}

\begin{abstract}
The objective of this work was to evaluate the effects of re-ensiling and bacterial inoculation on the quality of corn silage. The experiment was carried out in a $2 \times 2$ factorial design with or without inoculant (association of Lactobacillus plantarum and Propionibacterium acidipropionici), and with re-ensiling after 36 hours of aerobic exposure or only ensiling of the whole plant of 'BRS 1055' corn. The fermentative quality, nutritional parameters, dry matter losses, aerobic stability, and microbiological counts of silages were evaluated. Re-ensiling caused an increase of $\mathrm{pH}$ and in acetic acid and propionic acid concentrations, as well as in the dry matter (DM), crude protein, neutral detergent fiber, and neutral detergent fiber crude protein contents. Conversely, there was a reduction in the nonfiber carbohydrates concentration and in in vitro dry matter digestibility for the re-ensiled material. All changes were explained by the higher-effluent production and DM loss of re-ensiled material that was subjected to two compactions. Microbiology was not altered by the treatments. The use of inoculant altered ash content, but it did not influence other parameters. In contrast, re-ensiling after 36 hours of aerobic exposure caused a reduction in the nutritive value of corn silage and accentuated the DM losses.
\end{abstract}

Index terms: additives, aerobic deterioration, dry matter losses, re-ensiling.

\section{Características químicas, estabilidade aeróbia e contagem microbiológica de silagens de milho reensiladas com inoculante bacteriano}

\begin{abstract}
Resumo - $\mathrm{O}$ objetivo deste trabalho foi avaliar os efeitos da reensilagem e do uso de inoculante bacteriano sobre a qualidade da silagem de milho. $\mathrm{O}$ experimento foi realizado em delineamento fatorial $2 \times 2$, com o uso ou não de inoculante (associação de Lactobacillus plantarum e Propionibacterium acidipropionici), e reensilagem após 36 horas de exposição aeróbia ou somente com ensilagem da planta inteira de milho 'BRS 1055'. Avaliaram-se a qualidade fermentativa, os parâmetros nutricionais, as perdas de matéria seca, a estabilidade aeróbia e a contagem microbiológica das silagens. A reensilagem causou o aumento do $\mathrm{pH}$ e das concentrações dos ácidos acético e propiônico, assim como dos teores de matéria seca (MS), proteína bruta, fibra em detergente neutro e fibra em detergente neutro corrigida quanto a cinzas e proteínas. Em contrapartida, houve redução da concentração de carboidratos não fibrosos e da digestibilidade in vitro da matéria seca no material reensilado. Todas as alterações foram explicadas pela maior produção de efluentes e pela perda de MS do material reensilado, que foi submetido a duas compactações. A microbiologia não foi alterada pelos tratamentos. A utilização de inoculante alterou o teor de cinzas do material, mas não influiu nos demais parâmetros. No entanto, a reensilagem, após 36 horas de exposição aeróbia, provocou redução do valor nutritivo da silagem de milho e acentuou as perdas de MS.
\end{abstract}

Termos para indexação: aditivos, deterioração aeróbia, perdas de matéria seca, reensilagem.

\section{Introduction}

The purchase of silages has been a common activity in recent years in Brazil. Large-scale trade often results in re-ensiling of the material in the farm. This process includes the exposure of silage to air during opening and relocation. Later, the material should be re-ensiled in the farm of destination. This practice has been recently studied in Brazil (Michel et al., 2017; Lima et al., 2017) and in other parts of the world, as in Israel (Chen \& Weinberg, 2014). The re-ensiling is advantageous for producers who do not have an available area for planting, or machinery for planting 
and harvesting. In addition, producers who have irrigation, or are in privileged regions, can turn the sale of silage into a commercial strategy.

Studies on the effects of re-ensiling on the quality of corn silage are rare and recent (Chen \& Weinberg, 2014; Lima et al., 2017). These studies have proved that re-ensiling can be done without causing a negative effect on the quality of the roughage. Nevertheless, the excellence of this process depends on several factors, such as ambient temperature, processing time (Kung $\mathrm{Jr}, 2010$ ), and the presence of deteriorating aerobic microorganisms.

Yeasts are the microorganisms with the highestdeterioration potential, as they are resistant to silage $\mathrm{pH}$ (3.8) and have a fast growth. Filamentous fungi also exert harmful effects on silage, although they show a slow development (Muck, 2010). In addition, these fungi produce mycotoxins with potential to affect the animal performance and human health (Tangni et al., 2013).

The use of microbial inoculants may be an alternative to minimize the damage from the exposure to the air (Michel et al., 2017). The main microorganism found in the market of inoculants is Lactobacillus plantarum. These bacteria produces lactic acid which acts to reduce the $\mathrm{pH}$ of the ensiled mass and improves its anaerobic conservation (Santos et al., 2013). However, lactic acid is not effective to control microorganisms that cause aerobic deterioration. Additionally, propionic bacteria can be used because propionic acid is a potent anti-fungal agent (Zhang et al., 2010). The results of the work with inoculants are inconsistent. Filya et al. (2004) studied corn silages containing Propionibacterium acidipropionici, combined, or not, with $L$. plantarum, and observed a reduction of the number of yeasts and molds. Filya et al. (2006) worked with maize and sorghum silages subjected to the same treatments, and the plants did not support the effect of the inoculants. Studies with the addition of inoculants in re-ensiling corn silages are not yet described in the literature.

The objective of this work was to evaluate the influence of re-ensiling and the use of microbial additives on the physical, chemical, and microbiological traits in corn silage.

\section{Materials and Methods}

The corn cultivar BRS 1055 was planted at the experimental area of Embrapa Milho e Sorgo, in the municipality of Sete Lagoas, in the state of Minas Gerais, Brazil (19 $28^{\prime} \mathrm{S}, 44^{\circ} 15^{\prime} \mathrm{W}$, at $732 \mathrm{~m}$ altitude), in rows spaced at $70 \mathrm{~cm}$ apart.

The crop was subjected to a basal fertilizer application of $112 \mathrm{~kg} \mathrm{P}_{2} \mathrm{O}_{5}, 64 \mathrm{~kg} \mathrm{~K}_{2} \mathrm{O}$, and $32 \mathrm{~kg} \mathrm{NO}_{3} \mathrm{ha}^{-1}+0.5 \%$ $\mathrm{Zn}$. Subsequently, a top-dressing fertilization was made with $100 \mathrm{~kg} \mathrm{~N} \mathrm{ha}^{-1}$. The crop was irrigated, and harvesting was performed at 110 days. Immediately before harvesting, the crop was randomly sampled by collecting five samples within five linear meters. The number of plants, plant height, and plant weight were evaluated to calculate the green mass yield. The productivity of fresh matter was $59.2 \mathrm{Mg} \mathrm{ha}^{-1}$.

After harvesting with a forage harvester machine, the material was chopped into $1-2 \mathrm{~cm}$ particles. The chopped forage was sampled for chemical analysis of fresh material, immediately compacted by hand, and stored in experimental silos. The silos were composed of $20 \mathrm{~L}$ plastic buckets equipped with Bunsen valves to allow the release of fermentation gas. A cotton bag, containing about $2 \mathrm{~kg}$ dry sand, was placed inside each bucket, in order to cover the bucket bottom, to allow of the measurement of effluents (Pedroso et al., 2008).

The use of a microbial inoculant during ensiling and the re-ensiling of silage, after 36 hours of exposure to air, were evaluated. The treatments were arranged in a $2 \times 2$ factorial arrangement. The first factor was the inoculation (with or without) and the second factor was silage conservation in conventional system only (one process of ensilage), or re-ensiling. A randomized complete block design was applied with five replicates.

The inoculum used was composed of optional homofermentative bacteria Lactobacillus plantarum MA18/5U, and propionic bacteria Propionibacterium

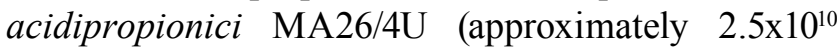

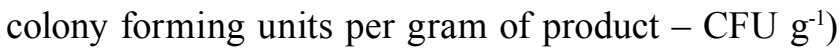
for each microorganism (Biomax Milho, Lallemand, Saint-Simon, France). The application was done at the ensiling. The product was diluted with water $\left(1 \mathrm{~g} \mathrm{~L}^{-1}\right)$, and uniformly sprayed with a costal sprayer onto the material, according to the manufacturer's recommendation. The re-ensiling process started 120 days after the silos were closed. The buckets were opened in a shed, the material was removed, and 
re-ensiled after 36 hours of exposure to air, starting at 7:00 h. During the aerobic exposure period, the temperature ranged from 23.5 to $29.6^{\circ} \mathrm{C}$, and the relative humidity was from 39 to $67 \%$.

The weight of the empty silos with lid and dry sand bags was recorded before ensiling. The silos were then filled with forage which was compacted, covered, sealed with adhesive tape, and then weighed. At opening, 56 days after the re-ensilage, silos belonging to the re-ensiling treatment were weighed both when filled and empty (after forage removal), to determine the production of gases and effluents. Forage was sampled to determine the dry matter content. At re-ensiling, the initial steps of ensiling were repeated, and silos were weighed again both when they were empty and when they were filled.

After 56 days of re-ensiling, all silos were weighed full for the determination of gas losses, according to the formula:

$\mathrm{G}=\{[($ Wen - SWen $) \times$ DMen $]-[($ Wop - SWen $) \times$ DMop $] \times 100\} /[($ Wen - SWen $) \times$ DMen $]$,

in which: $\mathrm{G}$ represents the gas losses ( $\%$ of dry matter); Wen is the weight of the bucket full $(\mathrm{kg})$, at ensiling; SWen is the set weight (empty bucket + lid + dry sand + bag) (kg), at ensiling; DMen is the forage dry matter content (\%), at ensiling; Wop is the weight of the bucket full $(\mathrm{kg})$, at opening; DMop is the forage dry matter content (\%), at opening.

The buckets were then opened, and silage was removed, sampled, and the set was weighed. Thus, the produced effluent was quantified according to the formula $\mathrm{EL}=(\mathrm{Wef} \times 1,000) / \mathrm{OMi}$, in which: $\mathrm{EL}$ represents the effluent losses $\left(\mathrm{kg} \mathrm{Mg}^{-1} \mathrm{OM}\right)$; Wef is the weight of effluent (weight of empty set after opening weight of empty set before filling); OMi is the amount of organic matter $(\mathrm{kg})$ ensiled.

The total dry matter loss was estimated by the difference among the final and initial dry weights of the experimental silos, in relation to the amount of dry silage, discounting the set at ensiling and at opening, according to the formula

$\mathrm{TDM}=\{[($ Wen - SWen $) \times$ DMen $]-[($ Wop - SWop $) \times$ DMop $] \times 100\} /[($ Wen - SWen $) \times$ DMen $]$,

in which: TDM is the total dry matter loss (\%); Wen is the weight of the full bucket ( $\mathrm{kg}$ ), at ensiling; SWen is the weight $(\mathrm{kg})$ of the set (empty bucket + lid + dry sand + bag), at ensiling; DMen is the forage dry matter content (\%), at ensiling; Wop is the weight of the full bucket $(\mathrm{kg})$, at opening; SWop is the weight $(\mathrm{kg})$ of the set (empty bucket + lid + dry sand + bag), at opening; DMop is the forage dry matter content (\%), at opening.

The methodology used for the analysis of losses was applied according to Pedroso et al. (2008). Gas, effluents, and total dry matter losses for re-ensiled silages were obtained from the sum of losses, at the first and final openings.

At the final opening, the samples were taken for determination of fermentative parameters, forage composition, aerobic stability, and total count of fungi, yeasts, and bacteria. For the evaluation of fermentative quality, the samples were pressed and the silage juice was extracted to determine $\mathrm{pH}$, ammoniacal nitrogen, and organic acids (lactic, acetic, propionic, and butyric acids). The $\mathrm{pH}$ was measured using a digital HI 221 potentiometer (Hanna Instruments, Woonsocket, RI, USA). Ammoniacal nitrogen level was obtained by the Kjeldahl method, without digestion. The levels of organic acids were determined by gas-liquid chromatography (GC-17A, Shimadzu, Kyoto, Japan).

The samples taken for analysis of chemical composition, morphological constituents, and fresh forage were oven-dried at $55^{\circ} \mathrm{C}$, for 72 hours, and subsequently processed in a knife mill to determine dry matter (DM) at $105^{\circ} \mathrm{C}$, ash, crude protein $(\mathrm{CP})$, and ethereal extract (EE) contents, according to AOAC (Cunniff, 1995). Cell-wall components were determined by the sequential method [neutral detergent fiber (NDF), acid detergent fiber (ADF), and lignin] according to Van Soest et al. (1991).

Residues of NDF and ADF were subjected to ash and crude protein analyses, in order to determine the values of neutral detergent insoluble protein (NDIP) and acid detergent insoluble protein (ADIP). These values were used to correct NDF and ADF for ash and protein (cpNDF, and cpADF). Non-fiber carbohydrate levels were calculated using the equation proposed by NRC (2001) as NFC $=100-(\%$ coNDF $+\% \mathrm{CP}+\%$ $\mathrm{EE}+\mathrm{MM}$ ), in which: coNDF is the correted neutral detergent fiber; $\mathrm{CP}$ is crude protein; $\mathrm{EE}$ is ether extract; and $\mathrm{MM}$ is the mineral matter.

In vitro dry matter digestibility (IVDMD) was determined according to Tilley \& Terry (1963), and adapted by Holden (1999) using DAISYII digestion apparatus (Ankon Technology, Faiport, NY, USA). The ruminal fluid was collected from a cannulated

Pesq. agropec. bras., Brasília, v.53, n.9, p.1045-1052, Sept. 2018 DOI: $10.1590 / \mathrm{S} 0100-204 \mathrm{X} 2018000900008$ 
cow fed a diet composed of $10 \mathrm{~kg}$ of corn silage (DM), and $3 \mathrm{~kg}$ commercial concentrate with $24 \% \mathrm{CP}$ (DM).

The evaluation of aerobic stability was carried out over 10 days in a room at $25 \pm 1^{\circ} \mathrm{C}$, in which the plastic buckets with $1.5 \mathrm{~kg}$ silage were placed. The silage temperature was monitored twice a day, at 12-hour intervals using mercury thermometers. Aerobic stability was calculated as the time after exposure to the air and showed a $2^{\circ} \mathrm{C}$ increase above the ambient temperature. When silage lost the aerobic stability, a sample was collected for microorganism countings.

Microbiological counts (yeasts, fungi, and aerobic bacteria) were done using a standard dispersion plate method (Pitt \& Hocking, 2009), according to the following described procedures. Initially, 25 grams of silage were diluted in $225 \mathrm{~mL}$ of $0.1 \%$ peptone water. Appropriate serial dilution (10-2 to 10-6) for each sample was performed in $0.1 \%$ peptone solution. Total bacterial counts were performed aerobically, and determined on plate count agar (PCA) after incubation for 24-48 hours at $36 \pm 1^{\circ} \mathrm{C}$. Total yeast counts were done using tryptone glucose yeast extract agar (TGY), after aerobic incubation for $24-72$ hours at $30 \pm 1^{\circ} \mathrm{C}$. The total fungal count was done using dichloran rose bengal chloramphenicol agar (DRBC), after aerobic incubation for 5-7 days at $25 \pm 1^{\circ} \mathrm{C}$, and there was no representative fungal development in all treatments during the period of incubation. All plates were daily examined. Total microbiological counts were expressed as colony forming units per gram (CFU g-1) and were transformed into $\log _{10}$ to obtain the lognormal distribution.

The results were subjected to statistical analysis in a $2 \times 2$ randomized complete block design with five replicates. The statistical model was calculated as $Y_{i j k}=\mu+R_{i}+I_{j}+N_{i j}+B_{k}+e_{i j k}$, in which: $Y_{i j k}$ is the observed response for the $\mathrm{i}^{\text {th }}$ level of the re-ensiling, and $\mathrm{j}^{\text {th }}$ level of the inoculant, in the $\mathrm{k}^{\text {th }}$ block; $\mu$ is the general mean; $R_{i}$ is the effect of the $i^{\text {th }}$ level of re-ensiling $(0$ or 36 hours); $I_{j}$ is the effect of the $j^{\text {th }}$ level of inoculant (with, or without application); $\mathrm{N}_{\mathrm{ij}}$ is the effect of re-ensiling and inoculant interaction; $B_{k}$ is the effect of block $k$ $(1,2,3,4,5)$; $\mathrm{e}_{\mathrm{ijk}}$ is the random error.

The averages were subjected to the interaction analysis, using the GLM procedure of SAS statistical program (SAS Institute Inc., Cary, NC, USA). If significant, averages were sliced. When the interactions were not significant, the factors were compared separately by the F-test, at 5\% probability. The variables were correlated using the Pearson's analysis, at $5 \%$ probability, by the $t$ test.

\section{Results and Discussion}

Corn composition after ensiling was: $298.35 \mathrm{~g} \mathrm{~kg}^{-1}$ DM, $39.59 \mathrm{~g} \mathrm{~kg}^{-1}$ ash, $76.00 \mathrm{~g} \mathrm{~kg}^{-1} \mathrm{CP}, 582.52 \mathrm{~g} \mathrm{~kg}^{-1}$ $\mathrm{NDF}, 303.41 \mathrm{~g} \mathrm{~kg}^{-1} \mathrm{ADF}$, and $36.59 \mathrm{~g} \mathrm{~kg}^{-1} \mathrm{EE}$.

According to the silage quality proposed by Tomich et al. (2003), all evaluated silages were of excellent standard of fermentation (Table 1). However, re-ensiling caused a rise of $\mathrm{pH}$ and of the acetic acid and propionic acid concentrations. Michel et al. (2017) also observed concentration increases of acetic and propionic acids in re-ensiled sorghum silages, in comparison with silages ensiled only once. In aerobiosis, lactic acid, as well as carbohydrates, proteins, and other compounds are substrates for the production of other acids, mainly acetic acid. The acids produced showed a $\mathrm{pKa}$ greater than that of the lactate, leading to an increase of medium $\mathrm{pH}$. This circumstance is determinant for the growth of bacteria of the genus Clostridium spp., which are responsible for silage deterioration and production of butyric acid (Wilkinson \& Davies, 2012).

In the study conducted by Filya et al. (2004), who also evaluated the association of Lactobacillus plantarum and Propionibacterium acidipropionici, the inoculant increased the concentrations of lactic acid and reduced those of acetate, without altering the content of propionic acid. However, in the present study, the use of bacterial inoculant did not influence the silage fermentation parameters. Filya et al. (2006) inoculated Lactobacillus plantarum and Propionibacterium acidipropionici in sorghum and corn silage, and did not observe any difference for acetic and propionic concentrations, but a rise of the lactic acid content.

The low-DM content of silage did not compromise silage quality as previously seen. The DM content of reensiled corn silages was higher than that of other silages analyzed in the present study. Chen \& Weinberg (2014) also reported the drying process of forage exposed to air, when corn and wheat silages were subjected to 48 hours of exposure to the environment. Nonetheless, Lima et al. (2017) and Michel et al. (2017) reported that DM content was not altered in corn and sorghum silages exposed for up to 48 and 24 hours, respectively. 
Silage drying is related to environmental factors, such as the direct action of the wind, and the influence of relative humidity of air and ambient temperature. In the present study, the DM increase was not enough to alter the other physicochemical characteristics of the re-ensiled silage.

Vieira et al. (2013) highlighted that corn silages of high-nutritional value have between 7 and $9 \%$ CP, 48 and 58\% NDF, and 23 and 30\% ADF. In the present work, all silage treatments were within these parameters, which evidences the excellent fermentative quality and high-nutritional value of corn silage produced. The values found for IVDMD corroborate the previous statement, as they are similar to the best corn hybrids evaluated by Vilela et al. (2008).

Re-ensiling caused a decrease of IVDMD and NFC contents. However, this process increased the percentages of NDF and cpNDF. These values are connected because the increase of cell wall components (Table 2), with the reduction of soluble carbohydrates, invariably results in decreased feed digestibility (Weiss, 1993). Additionally, there was an increase of CP content in re-ensiled materials as a consequence of the decrease of sugars, which resulted in a higher concentration (7.5\% higher) of these nitrogen compounds.

Table 1. Fermentative parameters of ensiled and re-ensiled corn silages treated with or without (control) bacterial inoculant (Lactobacillus plantarum + Propionibacterium acidipropionici).

\begin{tabular}{|c|c|c|c|c|c|c|c|c|}
\hline \multirow[t]{2}{*}{ Parameter } & \multicolumn{2}{|c|}{ Control } & \multicolumn{2}{|c|}{ With inoculant } & \multirow[b]{2}{*}{ SEM } & \multicolumn{3}{|c|}{$\mathrm{p}$-value } \\
\hline & Ensiled & Re-ensiled & Ensiled & Re-ensiled & & $\mathrm{I}$ & $\mathrm{R}$ & $\mathrm{I} \times \mathrm{R}$ \\
\hline $\mathrm{pH}$ & 3.80 & 3.94 & 3.79 & 3.87 & 0.02 & ns & $* *$ & $\mathrm{~ns}$ \\
\hline $\mathrm{NH}_{3}-\mathrm{N} / \mathrm{TN}\left(\mathrm{g} \mathrm{kg}^{-1}\right)$ & 82.38 & 80.04 & 82.30 & 69.54 & 0.35 & ns & ns & $\mathrm{ns}$ \\
\hline Lactic acid $\left(\mathrm{g} \mathrm{kg}^{-1} \mathrm{DM}\right)$ & 74.16 & 68.50 & 72.18 & 61.80 & 0.24 & ns & ns & $\mathrm{ns}$ \\
\hline Acetic acid $\left(\mathrm{g} \mathrm{kg}^{-1} \mathrm{DM}\right)$ & 14.46 & 39.68 & 12.00 & 30.32 & 0.33 & ns & ** & $\mathrm{ns}$ \\
\hline Propionic acid $\left(\mathrm{g} \mathrm{kg}^{-1} \mathrm{DM}\right)$ & 0.48 & 2.50 & 0.40 & 1.44 & 0.03 & ns & ** & $\mathrm{ns}$ \\
\hline Butyric acid $\left(\mathrm{g} \mathrm{kg}^{-1} \mathrm{DM}\right)$ & 1.52 & 0.40 & 0.56 & 0.02 & 0.03 & ns & ns & ns \\
\hline
\end{tabular}

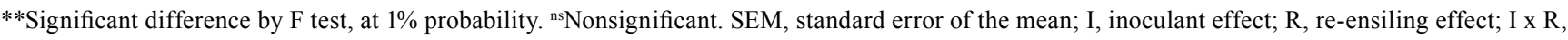
interaction.

Table 2. Chemical composition and in vitro dry matter digestibility of ensiled and re-ensiled corn silages treated with or without (control) bacterial inoculant (Lactobacillus plantarum + Propionibacterium acidipropionici).

\begin{tabular}{|c|c|c|c|c|c|c|c|c|}
\hline \multirow[t]{2}{*}{ Parameter $\left(\mathrm{g} \mathrm{kg}^{-1} \mathrm{DM}\right)$} & \multicolumn{2}{|c|}{ Control } & \multicolumn{2}{|c|}{ With inoculant } & \multirow[t]{2}{*}{ SEM } & \multicolumn{3}{|c|}{$\mathrm{p}$-value } \\
\hline & Ensiled & Re-ensiled & Ensiled & Re-ensiled & & I & $\mathrm{R}$ & $\mathrm{I} \times \mathrm{R}$ \\
\hline Dry matter (DM) & 276.50 & 290.52 & 276.54 & 297.08 & 0.26 & ns & $* *$ & $\mathrm{~ns}$ \\
\hline Ash & 43.28 & 44.12 & 39.66 & 42.9 & 0.04 & * & ns & $\mathrm{ns}$ \\
\hline Crude protein $(\mathrm{CP})$ & 79.82 & 84.36 & 76.44 & 83.82 & 0.06 & ns & $* *$ & $\mathrm{~ns}$ \\
\hline NDIP & 12.46 & 12.72 & 11.92 & 12.42 & 0.04 & ns & ns & $\mathrm{ns}$ \\
\hline ADIP & 8.40 & 7.78 & 7.68 & 7.76 & 0.04 & ns & ns & ns \\
\hline Ether extract (EE) & 35.32 & 36.12 & 35.90 & 36.56 & 0.11 & ns & ns & ns \\
\hline Neutral detergent fiber (NDF) & 509.82 & 549.46 & 536.44 & 579.7 & 0.59 & ns & $*$ & ns \\
\hline cpNDF & 474.28 & 520.08 & 506.0 & 545.6 & 0.57 & ns & * & $\mathrm{ns}$ \\
\hline Acid detergent fiber (ADF) & 284.22 & 290.56 & 295.52 & 302.5 & 0.39 & ns & ns & ns \\
\hline cpADF & 270.44 & 274.30 & 279.38 & 280.04 & 0.53 & $\mathrm{~ns}$ & ns & $\mathrm{ns}$ \\
\hline Lignin & 19.42 & 15.10 & 11.78 & 17.22 & 0.24 & ns & ns & ns \\
\hline Nonfiber carbohydrates (NFC) & 367.30 & 315.32 & 342.00 & 291.12 & 0.94 & ns & $* *$ & ns \\
\hline IVDMD & 705.58 & 658.34 & 686.76 & 659.92 & 0.65 & ns & ** & ns \\
\hline
\end{tabular}

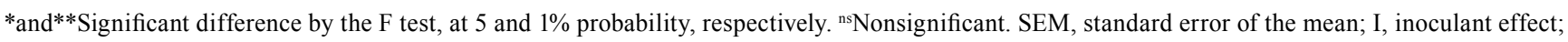
$\mathrm{R}$, re-ensiling effect; IxR, interaction; NDIP, neutral detergent insoluble protein; ADIP, acid detergent insoluble protein; cpNDF, neutral detergent fiber crude protein; cpADF, acid detergent fiber crude protein; and IVDMD, in vitro dry matter digestibility. 
Two factors act in re-ensiling for reducing NFC content. The first is the development of facultative aerobic and anaerobic microorganisms that ferment these sugars to organic acids and other fermentative products. The second factor is the increase of effluent losses, which carried soluble substances (Table 3). The mechanical action of compaction, performed twice in silage and re-ensiling - forces water to escape from plant cells (Jobim et al., 2007; Michel et al., 2017).

The use of inoculant was not able to alter forage composition, except for the decrease of ash content. But it has little practical relevance. In a recent study, Michel et al. (2017) found no effect of Lactobacillus plantarum + Propionibacterium acidipropionici on the bromatological composition, in vitro dry matter digestibility, and fermentation quality of sorghum silages.

The inoculation was performed in an attempt to lessen dry matter losses of fermentative origin in the re-ensiled material. Nevertheless, the use of inoculant did not alter DM losses, irrespective of origin (gas and effluent), or total (Table 3). Gas losses were similar in all treatments. However, there was an intensification of more than $20 \%$ in total DM losses of the re-ensiled material compared to the ensiled one. This can generate economic losses for the farmers who practice the re-ensiling. Köhler et al. (2013) found on average $10 \%$ DM losses in corn silage, which is similar to those values determined in the present study.

The aerobic stability of corn silages was similar in all treatments. On average, the evaluated silages heated after 136 hours of exposure to air (Table 4). In the present study, a higher concentration of acetic acid was observed in the re-ensiled material (Table 1). This fact could lead to an increased aerobic stability of these groups by the inhibition of yeast and mold growth (Tabacco et al., 2011). However, this result was not verified, and the inoculation of Lactobacillus plantarum and Propionibacterium acidipropionici was inefficient, similarly to the studies of Filya et al. (2004) and Michel et al. (2017).

Microbiological data showed that filamentous fungi did not develop in laboratory, regardless of inoculation or re-ensiling. Additionally, yeasts had a relevant development, but their count was below the threshold of $10^{5}$ colonies that Tabacco et al. (2009) considered for a corn silage prone to aerobic deterioration. This value exceeded at the time of loss of stability, showing its practicality as a parameter to be considered. There was no difference of yeast growth among treatments,

Table 3. Dry matter losses through gases, effluents, and total of ensiled and re-ensiled corn silages treated with or without (control) bacterial inoculant (Lactobacillus plantarum + Propionibacterium acidipropionici).

\begin{tabular}{|c|c|c|c|c|c|c|c|c|}
\hline \multirow[t]{2}{*}{ Loss } & \multicolumn{2}{|c|}{ Control } & \multicolumn{2}{|c|}{ Inoculant } & \multirow[t]{2}{*}{ SEM } & \multicolumn{3}{|c|}{$\mathrm{p}$-value } \\
\hline & Ensiled & Re-ensiled & Ensiled & Re-ensiled & & $\mathrm{I}$ & $\mathrm{R}$ & $\mathrm{I} \times \mathrm{R}$ \\
\hline Gases (\%) & 8.33 & 9.25 & 8.38 & 8.99 & 0.48 & ns & ns & $\mathrm{ns}$ \\
\hline Effluents $\left(\mathrm{kg} \mathrm{Mg}^{-1}\right)$ & 19.57 & 29.54 & 18.18 & 28.89 & 1.30 & ns & $* *$ & ns \\
\hline Total (\%) & 10.72 & 12.74 & 10.62 & 13.16 & 0.56 & ns & * & ns \\
\hline
\end{tabular}

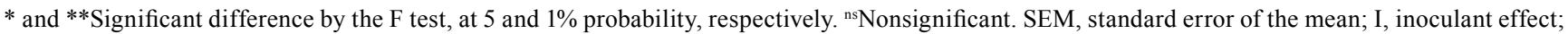
$\mathrm{R}$, re-ensiling effect; IxR, interaction.

Table 4. Aerobic stability and total microbiological count at silo opening, and at the time of loss of aerobic stability of reensiled corn silages with bacterial inoculant.

\begin{tabular}{|c|c|c|c|c|c|c|c|c|}
\hline \multirow[t]{2}{*}{ Parameter } & \multicolumn{2}{|c|}{ Control } & \multicolumn{2}{|c|}{ Inoculant } & \multirow[t]{2}{*}{ SEM } & \multicolumn{3}{|c|}{ p-value } \\
\hline & Ensiled & Re-ensiled & Ensiled & Re-ensiled & & $\mathrm{I}$ & $\mathrm{R}$ & $\mathrm{I} \times \mathrm{R}$ \\
\hline Aerobic stability (hours) & 144.00 & 141.60 & 156.00 & 105.60 & 13.83 & ns & ns & ns \\
\hline Bacteria $\left.\left(\log _{10} \mathrm{CFU} \mathrm{g}\right)^{-1}\right)^{(1)}$ & 5.35 & 5.37 & 4.41 & 5.94 & 0.30 & ns & ns & ns \\
\hline Yeast $\left.\left(\log _{10} \mathrm{CFU} \mathrm{g}\right)^{-1}\right)^{(1)}$ & 3.14 & 2.51 & 2.98 & 2.85 & 0.25 & ns & ns & ns \\
\hline Bacteria $\left.\left(\log _{10} \mathrm{CFU} \mathrm{g}\right)^{-1}\right)^{(2)}$ & 6.56 & 7.47 & 8.40 & 8.11 & 0.44 & ns & ns & ns \\
\hline Yeast $\left.\left(\log _{10} \mathrm{CFU} \mathrm{g}\right)^{-1}\right)^{(2)}$ & 7.90 & 5.74 & 8.21 & 7.89 & 0.44 & ns & ns & ns \\
\hline
\end{tabular}

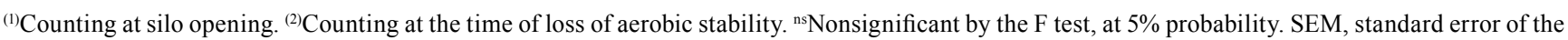
mean; I, inoculant effect; R, re-ensiling effect; IxR, interaction. 
both at opening and at the time of loss of stability. This occurrence corroborates the fact that the increase of acetic acid in the re-ensiled materials was not sufficient to alter microbial growth during the aerobic exposure, at least in the number of colonies. Lima et al. (2017) also did not find difference for molds, yeast, and bacteria growth among re-ensiled corn silages with 12 , 24 and 48 hours of air exposure.

In the present study, there was no representative growth of lactate-assimilating yeasts, cited by Tabacco et al. (2009) as responsible for the beginning of aerobic deterioration in the first 24 hours of exposure to oxygen. Gerlach et al. (2013) observed only an exponential growth of yeasts, fungi, and aerobic bacteria in corn silages after the fourth day of aerobic exposure. This period is very similar to the average number of hours for the loss of aerobic stability in silages from the present study.

Bacterial count was neither influenced by reensiling nor by the use of bacterial inoculant. Based on the similarity of concentration of produced organic acids and the bacterial count, it can be stated that the inoculant was not able to alter the bacterial profile of silage, but the epiphytic flora of forage supplanted it. Kristensen et al. (2010) reported that the number of lactic acid bacteria was three to five times higher in fresh corn silage than the inoculant dose used, therefore, there was no change in the microbiological count among silages of the control group and groups treated with bacterial inoculant. In addition, Filya et al. (2006) mentioned that in silages with $\mathrm{pH}$ below 4.0 , there is no production of propionic acid by the Propionibacterium acidipropionici. Possibly, it was the cause of the inoculant inefficiency to alter the microbiological and the fermentative characteristics of the inoculated silages in the present work.

\section{Conclusions}

1. Re-ensiling increases the dry matter losses through effluents and reduces the nutritive value of forage because it improves the neutral detergent fiber contents and reduces the nonfiber carbohydrates concentration.

2. The microbial inoculation (Lactobacillus plantarum + Propionibacterium acidipropionici) is not able to change the measured characteristics of corn ensiled or re-ensiled in any relevant aspect.

\section{Acknowledgments}

To Conselho Nacional de Desenvolvimento Científico e Tecnológico (CNPq) and to Coordenação de Aperfeiçoamento de Pessoal de Nível Superior (Capes), for financial support and granting of scholarships; to Universidade Federal de Minas Gerais (UFMG) and Embrapa Milho e Sorgo, for partnership in the development of the project; and to Instituto Nacional de Ciência e Tecnologia de Ciência Animal, for support.

\section{References}

CHEN, T.; WEINBERG, Z.G. The effect of relocation of wholecrop wheat and corn silages on their quality. Journal of Dairy Science, v.97, p.406-410, 2014. DOI: 10.3168/jds.2013-7098.

CUNNIFF, P. (Ed.). Official methods of analysis of AOAC International. $16^{\text {th }}$ ed. Washington: AOAC, 1995. Official Method 920.39, Method 942.05, Method 967.03, Method 981.10.

FILYA, I.; SUCU, E.; KARABULUT, A. The effect of Propionibacterium acidipropionici, with or without Lactobacillus plantarum, on the fermentation and aerobic stability of wheat, sorghum and maize silages. Journal of Applied Microbiology, v.97, p.818-826, 2004. DOI: 10.1111/j.1365-2672.2004.02367.x.

FILYA, I.; SUCU, E.; KARABULUT, A. The effects of Propionibacterium acidipropionici and Lactobacillus plantarum, applied at ensiling, on the fermentation and aerobic stability of low dry matter corn and sorghum silages. Journal of Industrial Microbiology and Biotechnology, v.33, p.353-358, 2006. DOI: 10.1007/s10295-005-0074-Z.

GERLACH, K.; ROB, F.; WEIB, K.; BÜSCHER, W.; SÜDEKUM, K.-H. Changes in maize silage fermentation products during aerobic deterioration and effects on dry matter intake by goats. Agricultural and Food Science, v.22, p.168-181, 2013. DOI: 10.23986/afsci.6739.

HOLDEN, L.A. Comparison of methods of in vitro dry matter digestibility for ten feeds. Journal of Dairy Science, v.82, p.17911794, 1999. DOI: 10.3168/jds.S0022-0302(99)75409-3.

JOBIM, C.C.; NUSSIO, L.G.; REIS, R.A.; SCHMIDT, P. Avanços metodológicos na avaliação da qualidade da forragem conservada. Revista Brasileira de Zootecnia, v.36, p.101-119, 2007. Suplemento especial.

KÖHLER, B.; OSTERTAG, J.; THURNER, S.; SPIEKERS, H. Dry matter losses of grass, lucerne and maize silages in bunker silos. Agricultural and Food Science, v.22, p.145-150, 2013. DOI: $10.23986 /$ afsci.6715.

KRISTENSEN, N.B.; SLOTH, K.H.; HOJBERG, O.; SPLIID, N.H.; JENSEN, C.; THØGERSEN, S. Effects of microbial inoculants on corn silage fermentation, microbial contents, aerobic stability, and milk production under field conditions. Journal of Dairy Science, v.93, p.3764-3774, 2010. DOI: 10.3168/ jds.2010-3136.

Pesq. agropec. bras., Brasília, v.53, n.9, p.1045-1052, Sept. 2018 DOI: $10.1590 / \mathrm{S} 0100-204 X 2018000900008$ 
KUNG JR., L. Aerobic stability of silage. In: ALFALFA \& FORAGE SYMPOSIUM AND CORN/CEREAL SILAGE CONFERENCE, Visalia. Proceedings. Visalia: [University of California], 2010. 14p.

LIMA, E.M. de; GONÇALVES, L.C.; KELLER, K.M.; RODRIGUES, J.A. dos S.; SANTOS, F.P.C.; MICHEL, P.H.F.; RAPOSO, V.S.; JAYME, D.G. Re-ensiling and its effects on chemical composition, in vitro digestibility, and quality of corn silage after different lengths of exposure to air. Canadian Journal of Animal Science, v.97, p.250-257, 2017. DOI: 10.1139/ cjas-2016-0005.

MICHEL, P.H.F.; GONÇALVES, L.C.; RODRIGUES, J.A.S.; KELLER, K.M.; RAPOSO, V.S.; LIMA, E.M.; SANTOS, F.P.C.; JAYME, D.G. Re-ensiling and inoculant application with Lactobacillus plantarum and Propionibacterium acidipropionici on sorghum silages. Grass and Forage Science, v.72, p.432-440, 2017. DOI: $10.1111 /$ gfs.12253.

MUCK, R.E. Silage microbiology and its control through additives. Revista Brasileira de Zootecnia, v.39, p.183-191, 2010. Suplemento especial. DOI: 10.1590/S1516-35982010001300021.

NRC. National Research Council. Nutrient requirements of dairy cattle. 7th ed. rev. Washington: National Academy Press, 2001.

PEDROSO, A. de F.; NUSSIO, L.G.; LOURES, D.R.S.; PAZIANI, S. de F.; RIBEIRO, J.L.; MARI, L.J.; ZOPOLLATTO, M.; SCHMIDT, P.; MATTOS, W.R.S.; HORII, J. Fermentation, losses, and aerobic stability of sugarcane silages treated with chemical and bacterial additives. Scientia Agricola, v.65, p.589594, 2008. DOI: 10.1590/S0103-90162008000600004.

PITT, J.I.; HOCKING, A.D. Fungi and food spoilage. $3^{\text {rd }}$ ed. London: Blackie Academic and Professional, 2009.

SANTOS, A.O.; ÁVILA, C.L.S; SCHWAN, R.F. Selection of tropical lactic acid bacteria for enhancing the quality of maize silage. Journal of Dairy Science, v.96, p.7777-7789, 2013. DOI: 10.3168/jds.2013-6782.

TABACCO, E.; PIANO, S.; CAVALLARIN, L.; BERNARDES, T.F.; BORREANI, G. Clostridia spore formation during aerobic deterioration of maize and sorghum silages as influenced by Lactobacillus buchneri and Lactobacillus plantarum inoculants. Journal of Applied Microbiology, v.107, p.1632-1641, 2009. DOI: $10.1111 / \mathrm{j} .1365-2672.2009 .04344 . x$.

TABACCO, E.; RIGHI, F.; QUARANTELLI, A.; BORREANI, G. Dry matter and nutritional losses during aerobic deterioration of corn and sorghum silages as influenced by different lactic acid bacteria inocula. Journal of Dairy Science, v.94, p.1409-1419, 2011. DOI: 10.3168/jds.2010-3538.

TANGNI, E.K.; PUSSEMIER, L.; VAN HOVE, F. Mycotoxin contaminating maize and grass silages for dairy cattle feeding: current state and challenges. Journal of Animal Science Advances, v.10, p.492-511, 2013.

TILLEY, J.M.A.; TERRY, R.A. A two-stage technique for the in vitro digestion of forage crops. Journal of British Grassland Society, v.18, p.104-111, 1963. DOI: 10.1111/j.1365-2494.1963. tb00335.x.

TOMICH, T.R.; PEREIRA, L.G.R.; GONÇALVES, L.C.; TOMICH, R.G.P.; BORGES, I. Características químicas para avaliação do processo fermentativo de silagens: uma proposta para qualificação da fermentação. Corumbá: Embrapa Pantanal, 2003. (Embrapa Pantanal. Documentos, 57).

VAN SOEST, P.J.; ROBERTSON, J.B.; LEWIS, B.A. Methods for dietary fiber, neutral detergent fiber, and nonstarch polysaccharides in relation to animal nutrition. Journal of Dairy Science, v.74, p.3583-3597, 1991. DOI: 10.3168/jds.S00220302(91)78551-2.

VIEIRA, V.C.; MARTIN, T.N.; MENEZES, L.F.G.; ASSMANN, T.; ORTIZ, S.; BERTONCELLI, P.; PIRAN FILHO, F.A.; SCHIMITZ, T.H. Caracterização bromatológica e agronômica de genótipos de milho para produção de silagem. Arquivo Brasileiro de Medicina Veterinária e Zootecnia, v.65, p.847-856, 2013. DOI: $10.1590 / \mathrm{S} 0102-09352013000300034$.

VILELA, H.H.; REZENDE, A.V. de; VIEIRA, P. de F.; ANDRADE, G.A.; EVANGELISTA, A.R.; ALMEIDA, G.B. de $\mathrm{S}$. Valor nutritivo de silagens de milho colhido em diversos estádios de maturação. Revista Brasileira de Zootecnia, v.37, p.1192-1199, 2008. DOI: 10.1590/S1516-35982008000700008.

WEISS, W.P. Predicting energy values of feeds. Journal of Dairy Science, v.76, p.1802-1811, 1993. DOI: 10.3168/jds.S00220302(93)77512-8.

WILKINSON, J.M.; DAVIES, D.R. The aerobic stability of silage: key findings and recent developments. Grass and Forage Science, v.68, p.1-19, 2012. DOI: 10.1111/j.1365-2494.2012.00891.x.

ZHANG, C.; BRANDT, M.J.; SCHWAB, C.; GÄNZLE, M.G. Propionic acid production by cofermentation of Lactobacillus buchneri and Lactobacillus diolivorans in sourdough. Food Microbiology, v.27, p.390-395, 2010. DOI: 10.1016/j. fm.2009.11.019. 